\section{Green Period Characteristics and Foliar Cold Tolerance in 12 Iris Species and Cultivars in the Yangtze Delta, China}

\author{
Danqing Li, Jiao Zhang, Jiaping Zhang, Kang Li, and Yiping Xia ${ }^{1}$
}

ADDITIONAL INDEX WORDs. herbaceous perennial, digital image analysis, evergreen, leaf lethal temperature, $\mathrm{LT}_{50}$

SUMMARY. Iris (Iris sp.) is a popular and widely planted herbaceous perennial. However, most iris species go dormant without any aesthetic quality for 5-6 months in the transition zone between the temperate and subtropical climates. To investigate the effects of species/cultivars, leaf shape, and air temperature conditions on the ability to stay green, 12 popular species and cultivars in the transition zone were evaluated. Iris tested included the following species: roof iris ( $I$. tectorum), japanese iris (I. japonica), long leafed flag (I. halophila), yellow flag (I. pseudacorus), blood iris (I. sanguinea), japanese water iris (I. ensata), and smallflower iris (I. speculatrix) and the following cultivars: 'Chinensis' milky iris (I. lactea var. chinensis), 'Bryce Leigh' louisiana iris (I. hexagonae), 'Black Swan' german iris (I.germanica), 'Careless Sally' siberian iris (I. sibivica), and 'Loyalty' japanese water iris (I. ensata). We conducted a 2 -year field study on mature iris populations and evaluated the percentage of green leaves during winter retention and spring recovery using a digital image analysis (DIA). Green period during this study was calculated using predicted sigmoid curves based on the percentage of green leaves. The present study revealed that iris species/cultivars and air temperatures had considerable influence on the duration of the green period. Both evergreen and deciduous iris phenotypes exist with three different leaf shapes, among which the average green period of fan-shaped leaf iris species and cultivars was the longest. Because there was no significant $(P=\mathbf{0 . 2 0 5})$ relationship between green period during this period and leaf lethal temperature $\left(\mathrm{LT}_{50}\right)$, new cultivars with long green periods may be achieved without a simultaneous loss of cold tolerance in iris.

I ris, a genus of 300 species, is one of the most popular ornamental perennials in the Northern Hemisphere (Austin and Waddick, 2005). However, a distinct drawback of this genus is that most species will be deciduous without any aesthetic quality as much as 5-6 months. Species/ cultivars with long green period (the period when at least $50 \%$ of the leaves are green) are preferred for landscape application. Obvious differences in the green period of iris were found, and of special interest is that several species and cultivars are evergreen in the Yangtze Delta, China. The delta is located in the transition zone between subtropical and temperate climates (Zhang et al., 2005), with asynchrony in growth among species and higher species diversity (Loreau and Hector, 2001). Irises from different origins have adapted to the climate in this

Department of Horticulture, College of Agriculture and Biotechnology, Zhejiang University, 866 Yuhangtang Road, Hangzhou, Zhejiang, 310058, China

${ }^{1}$ Corresponding author. E-mail: ypxia@zju.edu.cn.

doi: 10.21273/HORTTECH03692-17 region, such as the local species roof iris, japanese iris, and small-flower iris (China Flora, 1985), long-leafed flag and 'Chinensis' milky iris, which are native to northeast or northwest China, and most horticulturally important species and cultivars (Han, 2008; Li et al., 2016; Tang et al., 2005). In this regard, the existence of these irises in this region provides possibility for green period research from related herbaceous species and cultivars that differ obviously in foliar habits.

Green period characteristics during winter green-down and spring green-up deserve more attention for most herbaceous ornamental perennials because they contribute to the plants' ornamental value. Evergreen plants, which can retain their functional leaves throughout the year, are uncommon among herbaceous perennials compared with deciduous ones which are leafless for some part of their annual cycle (Kikuzawa and Lechowicz, 2011). Because both evergreen and deciduous iris phenotypes exist, better knowledge of the foliar color dynamics in winter and spring would be helpful to link with the factors that influence color retention and extended green period. Color changes during this period in the transition zones have been studied extensively in warm-season grasses. Pompeiano et al. (2014) found that zoysiagrass (Zoysia sp.) species/ cultivars provided significantly longer dormancy period than fine-leaved species/cultivars. Also, color retention could be extended by increasing the photoperiod in months with short daylengths (Esmaili and Salehi, 2012) and application of nitrogen and trinexapac-ethyl in bermudagrass [Cynodon dactylon (Richardson, 2002)].

Longer color retention has been associated with poorer cold tolerance in a number of plants (Okeyo et al., 2011; Qian et al., 2001; Schwab et al., 1996), which makes it hard to selectively breed for cultivars with an extended green period and strong foliar cold tolerance. Previously, we preliminarily evaluated foliar cold tolerance and green period in six cultivars of german iris, among which 'Bedtime Story' stayed green the longest (330 d/year), whereas 'Caligula' was the shortest at $269 \mathrm{~d}$ and had much poorer cold tolerance than that of 'Bedtime Story' in Hangzhou, China (Wang et al., 2014). However, the relationship between green period and foliar cold tolerance is still not clear in iris. More iris species and cultivars need to be studied to have a better understanding of the relationship between these two traits.

This study quantified the winter color retention (discoloration) and spring recovery response of 12 iris species/cultivars in a field environment in the Yangtze Delta, China. Moreover,

\begin{tabular}{lllc}
\hline $\begin{array}{l}\text { Units } \\
\begin{array}{l}\text { To convert U.S. to SI, } \\
\text { multiply by }\end{array}\end{array}$ & U.S. unit & SI unit & $\begin{array}{l}\text { To convert SI to U.S., } \\
\text { multiply by }\end{array}$ \\
\hline 0.3048 & $\mathrm{ft}$ & $\mathrm{m}$ & 3.2808 \\
0.0929 & $\mathrm{ft}^{2}$ & $\mathrm{~m}^{2}$ & 10.7639 \\
2.54 & inch $(\mathrm{es})$ & $\mathrm{cm}$ & 0.3937 \\
25.4 & inch $(\mathrm{es})$ & $\mathrm{mm}$ & 0.0394 \\
$\left({ }^{\circ} \mathrm{F}-32\right) \div 1.8$ & ${ }^{\circ} \mathrm{F}$ & ${ }^{\circ} \mathrm{C}$ & $\left({ }^{\circ} \mathrm{C} \times 1.8\right)+32$
\end{tabular}


the relationship between green period, calculated using predicted sigmoid curves, and foliar cold tolerance, measured using $\mathrm{LT}_{50}$, was studied to provide a theoretical basis for molecular marker-assisted breeding of new cultivars that combine the characteristics of a long green period and improved foliar cold tolerance.

\section{Materials and methods}

Plant materials and establishMENT. The experiment was conducted from Sept. 2014 to May 2016 on mature iris populations at the Resources Nursery for Flower Bulbs and Herbaceous Perennials, Zhejiang University, Hangzhou, China (lat. $29^{\circ} 11^{\prime} \mathrm{N}$ to $30^{\circ} 33^{\prime} \mathrm{N}$, long. $118^{\circ} 21^{\prime} \mathrm{E}$ to $120^{\circ} 30^{\prime} \mathrm{E}$ ). On 10 Sept. 2013, uniformly sized bare rhizomes of each species/cultivar, with an average maximum width measured by an electronic digital caliper (Syntek, Hangzhou, China) and shown in Table 1 , were obtained from clonally propagated plants. Experimental plots of each species/cultivar planted at 20 plants $/ \mathrm{m}^{2}$ in a silt loam soil were $1.5 \times 1.5 \mathrm{~m}$ with three replications and arranged in a complete randomized block design. Conventional management and fertilization procedures for irises in East China were adopted as $\mathrm{Hu}$ and Xiao (2012) recommended. An on-site intelligent temperature and humidity recorder (ZDR-F20; Zeda Instruments, Hangzhou, China) monitored daily air temperature (Fig. 1).

In Table 1, relative chlorophyll content of functional leaves (the third and fourth actively growing leaves from central part on both sides of a plant) was determined by a chlorophyll meter (SPAD-502 PLUS; Konica Minolta Sensing, Osaka, Japan) to compare the leaf color differences among 12 irises. Green period, namely the number of days per year when the percentage of green leaves in a population exceeding 50\% (Guo et al., 2006), was obtained by visual rating during 2012-14. Leaf width was measured at the maximum width of functional leaves. Leaf shape of iris species/cultivar was classified based on their foliar shape and characteristics. Fan-shaped iris leaves are usually hypertrophied and arrayed into a fan shape. Sword-shaped leaf irises have erect and relatively hard leaves, whereas bar shaped-leaf ones have thin and soft blades.

Digital IMAge ANALYSIS OF THE PERCENTAGE OF GREEN LEAVES AND THE CALCULATION OF GREEN PERIOD. Iris winter color retention and spring recovery were evaluated on 10 -d intervals, using DIA techniques to quantify the percentage of green leaves for each plot (with $100 \%$ being full retention and $0 \%$ being completely withered). Digital images were taken with a digital camera (EOS 60D; Canon, Tokyo, Japan) and analyzed individually by MATLAB (version R2016a maci64; MathWorks, Natick, MA). Because the leaves of several iris species/ cultivars are long and perpendicular to the ground, the top-down image used in turfgrass (Richardson et al., 2001) was not applicable for determining the percentage of green leaves in iris. A tripod $1.2 \mathrm{~m}$ in height was used to fix the camera, and the lens was mounted down at a $45^{\circ}$ angle from a horizontal axis. This allowed the camera to be positioned in such a way that the images taken would be similar to a person observing plants in the plot. A script file was developed in the MATLAB programming language using color values in the hue, saturation, and brightness (HSB) system. To selectively identify iris green leaves, a hue ranging from $60^{\circ}$ to $200^{\circ}$, a saturation ranging from $10 \%$ to $100 \%$, and a brightness ranging from $10 \%$ to $100 \%$ were adopted after preliminary work on the pictures, and the number of selected green pixels (selectPixCntgreen) was obtained (Fig. 2). Similarly, the number of selected brown pixels for withered leaves was recorded as selectPixCnt-brown, which

Table 1. Introduction, classification, rhizome size, and foliar characteristics of the 12 iris species/cultivars used to analysis green period characteristics and foliar cold tolerance.

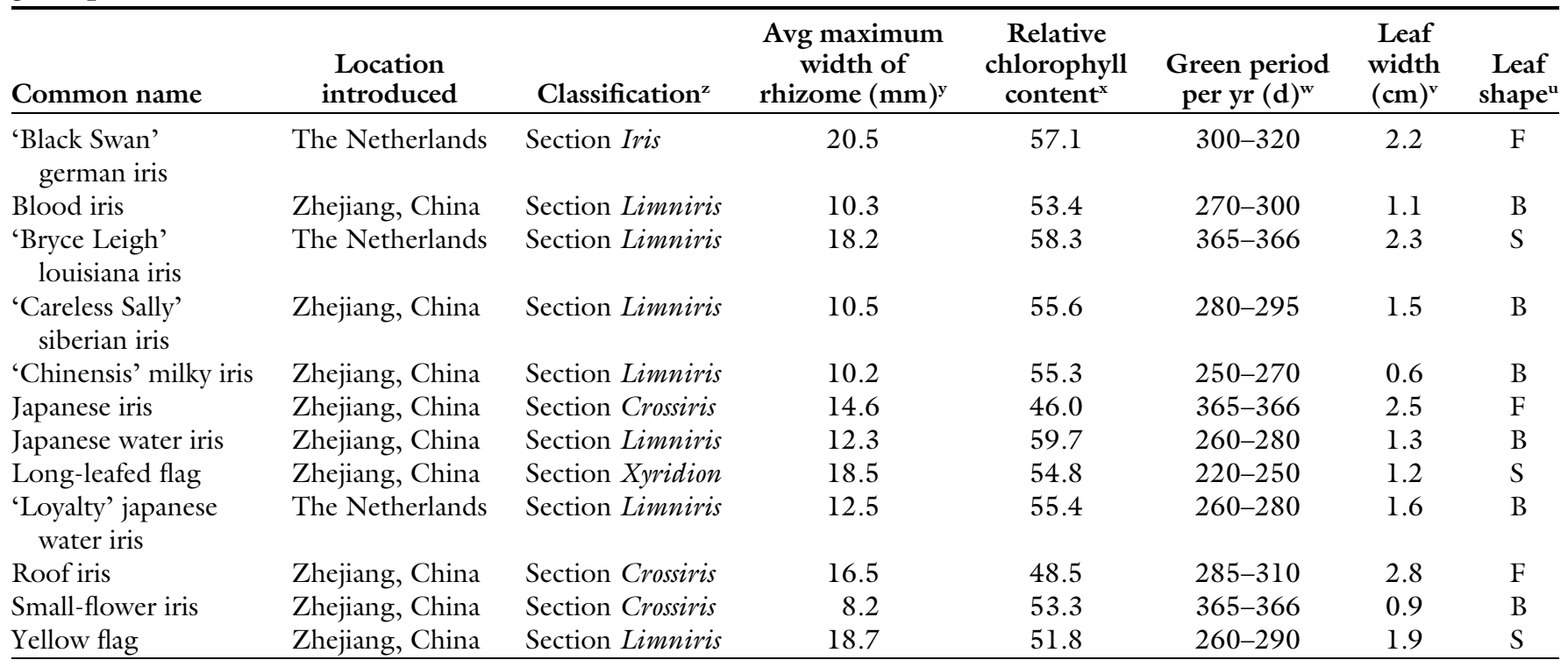

${ }^{\mathrm{z}}$ Species/cultivars are classified based on the classification standard of the American Iris Society.

${ }^{y}$ Average maximum width of rhizome was measured by an electronic digital caliper (Syntek, Hangzhou, China); $1 \mathrm{~mm}=0.0394$ inch.

${ }^{x}$ Relative chlorophyll content of functional leaves was determined by a chlorophyll meter (SPAD-502 PLUS; Konica Minolta Sensing, Osaka, Japan).

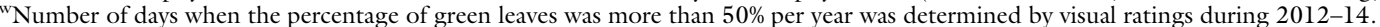

'Leaf width was measured at the maximum width of functional leaves; $1 \mathrm{~cm}=0.3937$ inch.

${ }^{\mathrm{u}} \mathrm{B}=$ bar shaped leaf; $\mathrm{F}$ = fan shaped leaf; $\mathrm{S}$ = sword shaped leaf. 

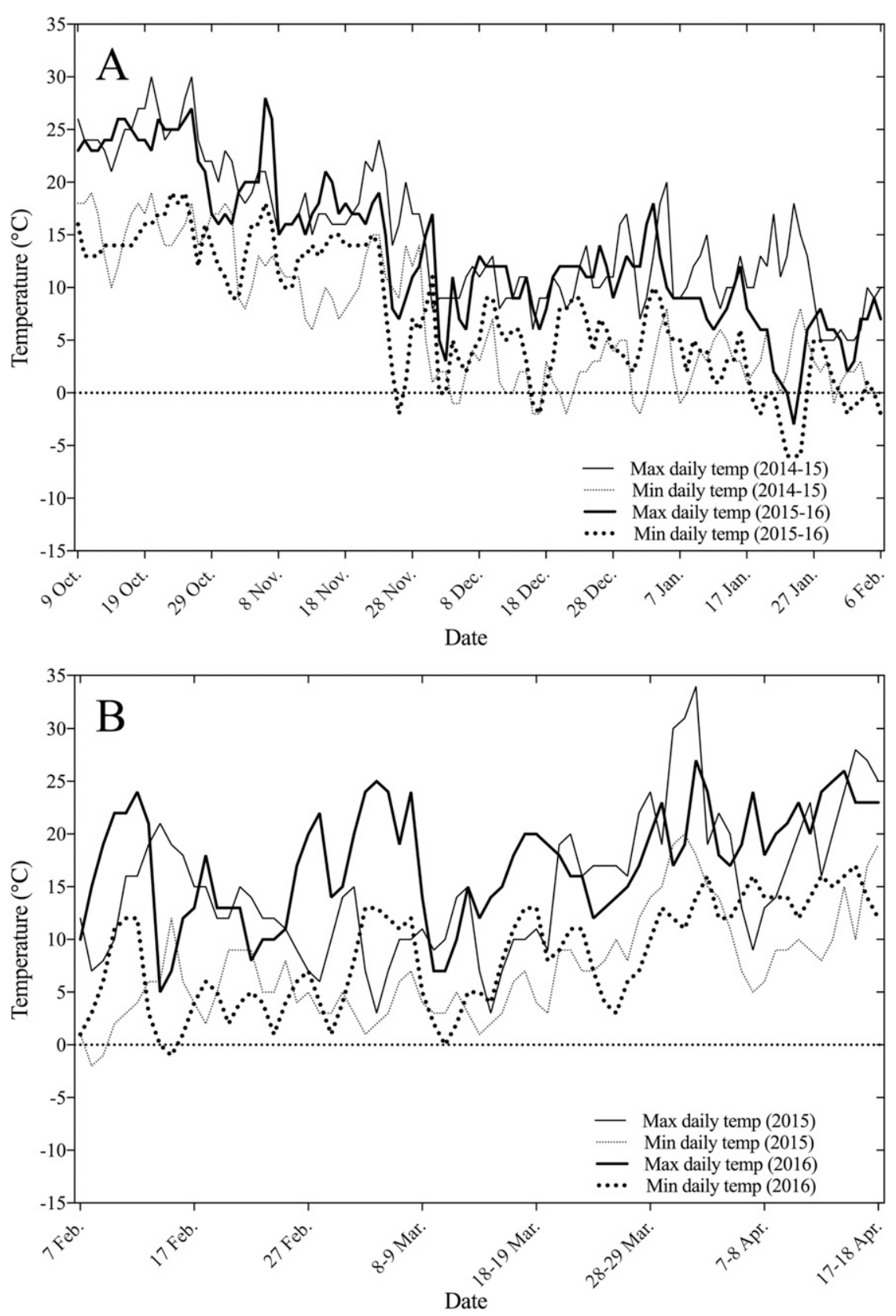

Fig. 1. Maximum and minimum daily temperature recorded at $2 \mathrm{~m}(6.6 \mathrm{ft})$ above the soil surface during the entire (A) green-down and (B) green-up period according to the experimental time from 2014 to 2016. Daily air temperature was monitored by an on-site intelligent temperature and humidity recorder (ZDRF20; Zeda Instruments, Hangzhou, China). Dates in front of "-" indicate dates of 2016 whereas dates behind " - " indicate dates of $2015 ;\left(1.8 \times{ }^{\circ} \mathrm{C}\right)+32={ }^{\circ} \mathrm{F}$.

was achieved using a hue range from $0^{\circ}$ to $60^{\circ}$, a saturation range from $30 \%$ to $100 \%$, and a brightness range from $45 \%$ to $100 \%$. Thus, green leaves (percent) $=$ selectPixCnt-green/ (selectPixCnt-green + selectPixCntbrown). In both years, different iris species and cultivars were evaluated for $120 \mathrm{~d}$ for green-down (from 9 Oct.) and for $70 \mathrm{~d}$ for green-up (from 7 Feb.) when the average minimum air temperature was below performed using the following sigmoid variable slope model:

green leaves $($ percent $)=[$ minimum $+($ maximum - minimum $)] /\left\{1+10^{[(\mathrm{D} 50-\mathrm{X}) \text { slope }]}\right\}$,

where $\mathrm{X}$ is number of days after a discretionary time zero (DGD and DGU, respectively, for green-down and green-up), and $\mathrm{D}_{50}$ and slope are estimated model parameters. $D_{50}$ is the number of days in which each species/cultivar was determined to be halfway between its maximum and minimum green leaf ratio in this study, and slope defines the steepness of the predicted curve. A sum of squares reduction F-test was used to determine whether iris species or cultivar significantly affected the percentage of green leaves during green-down and greenup. Green period in this study is the period when more than $50 \%$ of the total leaves are green during the experiment time and was determined when Eq. [1] calculated the percentage of green leaves as $\geq 50 \%$. All computations were performed with SPSS (version 22.0; IBM Corp, Armonk, NY), and GraphPad Prism (version 6.0; GraphPad Software, La Jolla, $\mathrm{CA}$ ) was used for predicted curves (Motulsky and Christopoulos, 2004) and figures.

Determination of Leaf $\mathbf{L T}_{\mathbf{5 0}}$. Uniform functional leaves were randomly chosen from three plots of each species/cultivar between 10 and 20 Sept. 2014 and 2015 when iris species/cultivars grew vigorously (average maximum air temperature was $\approx 25^{\circ} \mathrm{C}$ ). All experimental leaves were wrapped separately in sampling bags and taken to the laboratory immediately. After $12 \mathrm{~h}$ artificial cold accumulation in a refrigerator at $4{ }^{\circ} \mathrm{C}$, leaves were washed thoroughly with running tap water, rinsed three times with ultrapure water (Chengdu Youpu Biotechnology, Chengdu, China) (Zhang et al., 2013b), and blotted dry on filter paper. Next, leaves of each iris were put in separate sealed plastic bottles for different lowtemperature treatments. A cooling device (HX-3030; Hannuo Instruments, Shanghai, China) was used to drop the temperature at a rate of $0.4{ }^{\circ} \mathrm{C} / \mathrm{min}$. All experimental materials were placed into the device when the internal temperature had dropped 

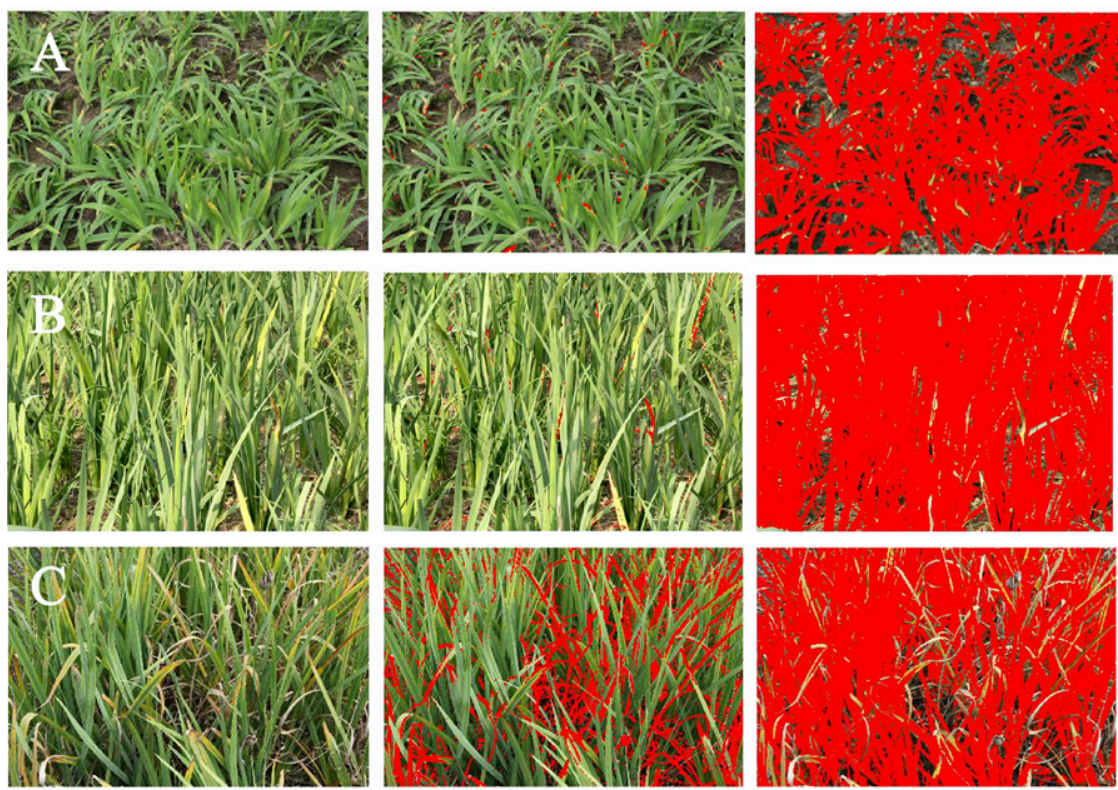

Fig. 2. Digital image analysis of (A) roof iris, (B) 'Bryce Leigh' louisiana iris and (C) 'Loyalty' japanese water iris plots on the first day of green period study. Each row from left to right is the original picture, the picture with selected brown pixels (withered leaves) in red and the picture with selected green pixels (green leaves) in red. Color masking based on defined hue, saturation and brightness (HSB) thresholds in MATLAB (version R2016a maci64; MathWorks, Natick, MA).

from room temperature to $4^{\circ} \mathrm{C}$. After $1.5 \mathrm{~h}$, one sample of each species/ cultivar was removed. The same protocol was applied every $1.5 \mathrm{~h}$ at the following temperatures: $4,0,-4,-8$, and $-12{ }^{\circ} \mathrm{C}$. The leaves of each iris that had been removed from the device were placed in a refrigerator at $4{ }^{\circ} \mathrm{C}$ and thawed for $6 \mathrm{~h}$.

The experimental leaves were cut into 3-mm-wide sections at equivalent fresh weight of $0.30 \mathrm{~g}$ to determine relative EC (REC). In addition, the electrolyte leakage was measured by a digital conductivity meter (DDS12A; Ohaus Instruments, Shanghai, China) using the methods of $\mathrm{Li}$ (2000) with a small modification. Briefly, every sample of leaves was incubated in $30 \mathrm{~mL}$ ultrapure water at room temperature $\left(25 \pm 1{ }^{\circ} \mathrm{C}\right)$ for $15 \mathrm{~h}$ and obtained conductivity of treated leaves, then incubated in a boiled water bath for $20 \mathrm{~min}$ and obtained conductivity of boiled leaves. Relative value was calculated as follows: REC (percent) = (conductivity of treated leaves/conductivity of boiled leaves $) \times 100$. Next, the leaf $\mathrm{LT}_{50}$ of each iris was determined with a nonlinear curve fit of the REC data using the Logistic equations in Origin Pro (version 9.1; OriginLab Corp., Northampton, MA). Determinations were repeated three times for each iris. One-way analysis of variance and Duncan's multiple range test were used to compare significant $(P \leq 0.5)$ differences among the different species and cultivars using SPSS.

\section{Results}

Green-Down. Climate conditions in the Yangtze Delta during 2014 green-down were more favorable for iris color retention, even though slight differences were observed for daily maximum and minimum air temperature during the 2 -year field study. The average minimum daily air temperatures were 6.98 and $7.45^{\circ} \mathrm{C}$, and the maximum daily air temperatures were 15.15 and $13.05^{\circ} \mathrm{C}$ during the 2014 and 2015 green-down, respectively (Fig. 1A). Considering the $\mathrm{cu}^{-}$ mulative GDD during green-down, the first year reached 728 GDD, 70.5 GDD more than 2015. During the first year of the study, the daily maximum air temperatures were below $10{ }^{\circ} \mathrm{C} 27$ times, and the daily minimum air temperatures were below $0{ }^{\circ} \mathrm{C}$ nine times, whereas they were below $10{ }^{\circ} \mathrm{C} 42$ times and $0{ }^{\circ} \mathrm{C}$ 12 times in 2015.

Iris species $(P<0.001)$ and cultivars $(P<0.001)$ significantly affected color retention in both years based on the result of F-test (data not shown). The sigmoid models provided a representative fit of the data to describe the dynamics of the predicted green-down curves (Fig. 3) and had average $R^{2}$ values of 0.9749 and 0.9790 , respectively, in 2014 and 2015 (Table 2). The green period of each iris was calculated by predicted green-down curves. The results showed that there were significant differences among species and cultivars of the same leaf shape, except for 'Careless Sally' siberian iris and 'Chinensis' milky iris for both years. The average green periods of the different leaf shapes of irises were longer in the first year than in the second year during green-down, with fan-shaped leaves having the longest green period ( 101.5 and $98.4 \mathrm{~d}$ in 2014 and 2015 , respectively) whereas bar-shaped leaves having the shortest ones (59.0 and $50.7 \mathrm{~d}$ in 2014 and 2015, respectively). Japanese iris, small-flower iris and 'Bryce Leigh' louisiana iris with different leaf shapes could be classified as evergreen iris type because their percentages of green leaves were always more than $50 \%$ during the study from fall to the next spring, whereas the other nine iris species/cultivars lost functional leaves. The average $\mathrm{D}_{50} \mathrm{~S}$ for evergreen and deciduous species / cultivars were 62.3 and 94.4 in 2014 , respectively. They were significantly longer than those for evergreen and deciduous species/cultivars in 2015 at 54.8 and 83.5 , respectively. By contrast, the average slopes of the sigmoid curves for evergreen and deciduous iris species/cultivars showed the opposite change trend with the $\mathrm{D}_{50}$ data.

Green-up. Overall, environmental conditions during the 2016 growing season were more favorable for spring green-up (Fig. 1B). The cumulative GDD indicated that 2016 reached 548.5 GDD, 131 GDD higher than 2015 at the end of green-up. Moreover, the daily maximum air temperatures were below $10{ }^{\circ} \mathrm{C}$ five times, and the daily minimum air temperatures were below $0{ }^{\circ} \mathrm{C}$ one time during green-up in 2016 , whereas they were below $10{ }^{\circ} \mathrm{C}$ 14 times and below $0{ }^{\circ} \mathrm{C}$ two times in 2015. The cumulative GDD declined significantly between 30 and 40 DGU compared with the initial stage in the first year of the study and were 82.5 and 27 GDD lower than the 

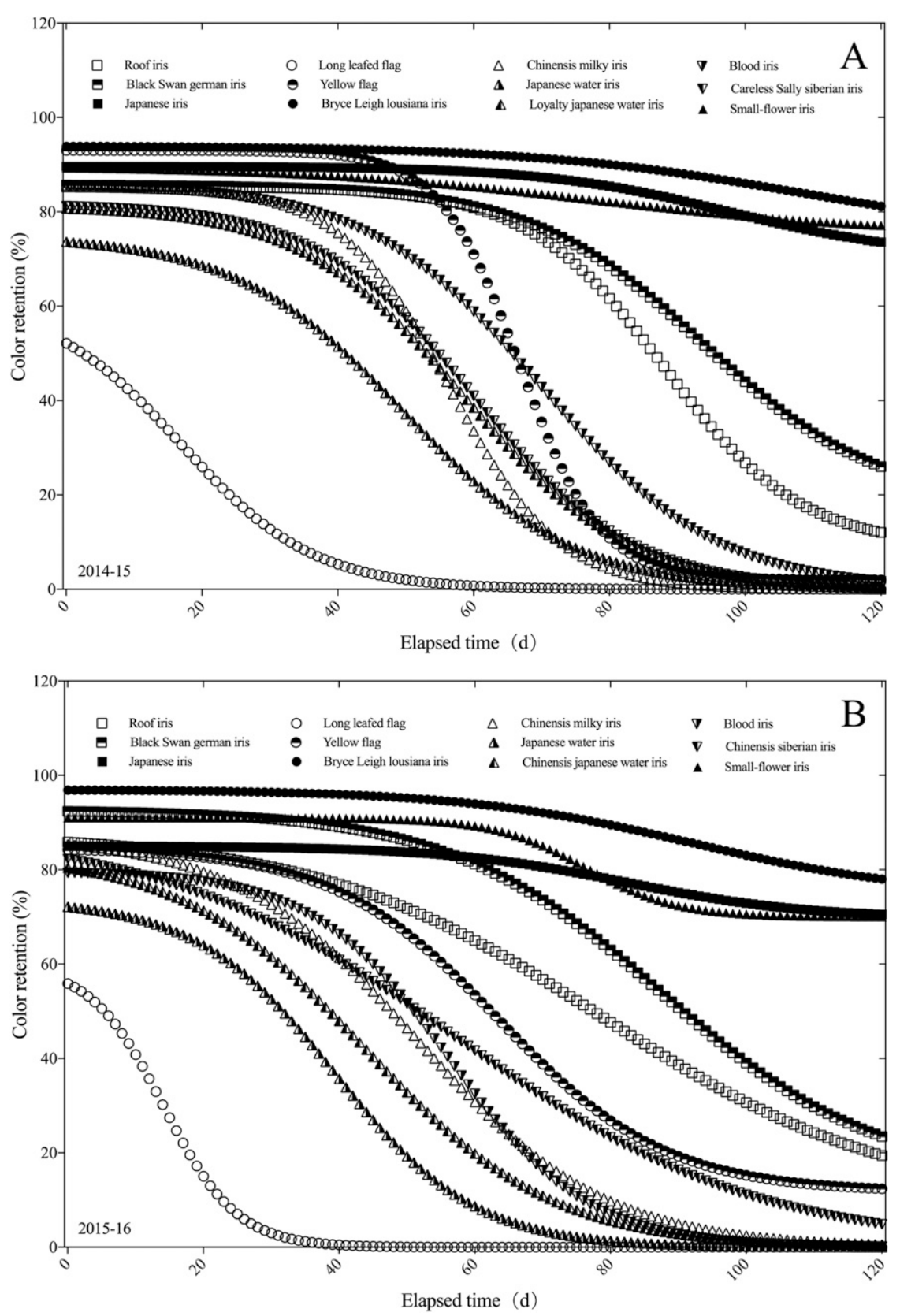

Fig. 3. (A) Predicted winter green-down curves for 12 iris species/cultivars from 2014 to 2015 . (B) Predicted winter green-down curves for 12 iris species/ cultivars from 2015 to 2016.

same stage in 2016, respectively. This might have had considerable influence on spring color recovery of irises.

As with winter color retention, iris species $(P<0.001)$ and cultivars $(P<0.001)$ also significantly affected spring color recovery in both years. The green periods of all evergreen iris types were $70 \mathrm{~d}$, whereas the average number of days for the deciduous types to reach $50 \%$ green leaves was 17.0 in the first year and 23.8 in the second year (Fig. 4; Table 2). The average $\mathrm{D}_{50} \mathrm{~s}$ of evergreen and deciduous iris phenotypes were 43.0 and $28.1 \mathrm{~d}$ in 2016 , respectively, which were clearly shorter than that in 2015 at 51.4 and $40.1 \mathrm{~d}$, respectively. By contrast, the average slope of the predicted curves for evergreen iris phenotypes in 2015 was significantly higher than that in 2016 , indicating that their percentage of green leaves increased rapidly for a while during the 2015 green-up. The difference of the average slope for deciduous species/cultivars between $2015(0.0479)$ and $2016(0.0492)$ was minimal. The average green periods of the different leaf shapes of irises during the 2015 green-up were shorter than those during the 2016 green-up. Within the three leaf shapes of irises, the average green periods of the barshaped leaf irises were the shortest at 19.7 and $21.8 \mathrm{~d}$ in 2015 and 2016, respectively. The biggest difference (14.6 d) of the average green periods in both years was observed in the sword-shaped leaf irises. Among the same leaf shape, the difference of the average green periods between japanese water iris $(0 \mathrm{~d})$ and smallflower iris $(70 \mathrm{~d})$ was the largest during green-up in both years.

RELATIONSHIP BETWEEN GREEN PERIOD AND FOLIAR COLD TOLERANCE. In this study, leaf $\mathrm{LT}_{50}$, the most intuitive index of foliar cold tolerance, was found to be species specific in iris (Table 3). The leaf $\mathrm{LT}_{50} \mathrm{~s}$ of deciduous iris type ranged from 0.6 to $-3.4^{\circ} \mathrm{C}$, and their mean value was $-1.6{ }^{\circ} \mathrm{C}$, whereas evergreen type exhibited a lower leaf $\mathrm{LT}_{50}$, and their mean value was $-4.3{ }^{\circ} \mathrm{C}$. The results of the present study indicated that evergreen phenotypes showed a lower leaf $\mathrm{LT}_{50}$ than that of deciduous phenotypes in the same leaf shape. No matter whether iris types were evergreen or deciduous, fan-shaped leaves showed poorest cold tolerance. Significant differences among barshaped leaf irises were observed; for example, the leaf $\mathrm{LT}_{50}$ of japanese water iris was $-1.0^{\circ} \mathrm{C}$, whereas that of its relevant cultivar Loyalty japanese water iris was $-3.4^{\circ} \mathrm{C}$. Small-flower iris with bar-shaped leaves had the lowest leaf $\mathrm{LT}_{50}$ among all the species and cultivars in this study.

Considering green period during this study, significant differences were observed among deciduous iris phenotypes while evergreen ones always stayed green (Table 3). Fan-shaped leaf irises had the longest average green period $(148.0 \mathrm{~d})$ and the highest average leaf $\operatorname{LT}_{50}\left(-0.6{ }^{\circ} \mathrm{C}\right)$. By contrast, the average green period of bar-shaped leaf irises was the shortest $(75.9 \mathrm{~d})$; however, their average leaf $\mathrm{LT}_{50}$ was similar to that of swordshaped leaf irises. Similarly, there were no significant differences between the leaf $\mathrm{LT}_{50}$ of 'Black Swan' german iris and japanese water iris, and among long leafed flag, blood iris, and japanese iris, whereas substantial differences were seen in their green periods. 

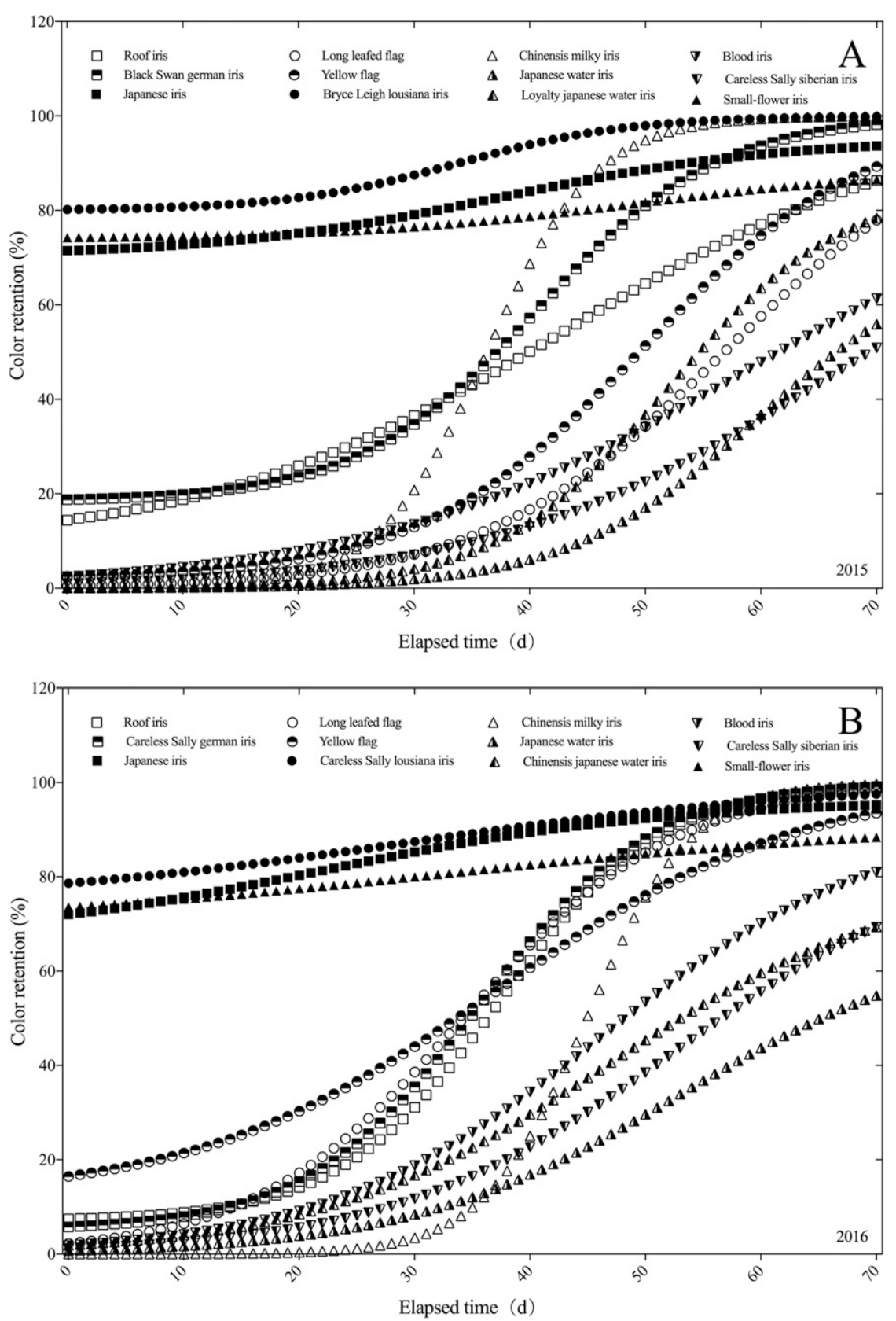

Fig. 4. (A) Predicted spring green-up curves for 12 iris species/cultivars in 2015. (B) Predicted spring green-up curves for 12 iris species/cultivars in 2016.

The results from linear regression analysis showed that there were no significant $(P=0.205)$ relationships between green period during the entire green-down and green-up period and leaf $\mathrm{LT}_{50}$ in iris (Table 4). Because leaf $\mathrm{LT}_{50}$ and cold tolerance are negatively correlated, we concluded that there was no association of green period in this study with foliar cold tolerance by artificial cold acclimation.

\section{Discussion}

In this study, we applied a DIA technique to get foliar color data for possible to apply this method to measure the percentage of green leaves in iris.

The results of this study clearly demonstrated that iris species and cultivars have a significant impact on the percentage of green leaves during green-down and green-up, which was similar to a study on zoysiagrass in southern Europe (Pompeiano et al., 2014). There are both evergreen and deciduous iris species/cultivars with fan-shaped, sword-shaped, or barshaped leaves. Thus, leaf shape had no obvious association with green period in iris. Leaf texture, such as leaf thickness, deposits of waxes, and the epidermis, might affect winter performance (Adams et al., 2004). Analyzing the climate conditions, we found that both early freezing events during green-down and continuous low temperatures during green-up shortened the green period of irises. Bermudagrass and zoysiagrass both discolor and growth halt when the air temperature is lower than $10{ }^{\circ} \mathrm{C}$, and soil temperatures are lower than $16{ }^{\circ} \mathrm{C}$ (Baltensperger, 1962). However, compared with the deciduous iris type, the changes in air temperature had less of an effect on the percentage of green cover in the evergreen iris type.

The biggest difference between turfgrass and irises is that there are evergreen iris phenotypes which can retain green functional leaves throughout the year in the Yangtze Delta. The 2 -year field observation data were in agreement with previous reports that japanese iris, small-flower iris, and louisiana iris could stay green during winter in this region (Zhang et al., 2013a; Zhou et al., 2010), although differences in climate conditions partially affected their winter performances in both years. Louisiana irises demonstrated better winter color retention and are widely used for their evergreen trait in the Yangtze Delta (Yin and Cheng, 2010; Zhang, 2012). We also found there were different levels of deciduousness in iris, for example, blood iris, japanese water iris, and long-leafed flag would go dormant and lose color around December, whereas roof iris, german iris and yellow flag totally lost functional leaves until January. For daylily (Hemerocallis sp.), another popular herbaceous perennial, evergreen, semievergreen, and deciduous 
Table 2. Predicted green period and estimated model parameters of Eq. [1] (green leaves (percent) $=[$ minimum $+($ maximum minimum $\left.)] /\left\{1+10^{[(\mathrm{D} 50-\mathrm{X}) \text { slope }]}\right\}\right)$ for the 12 iris species/cultivars during green-up or green-down.

\begin{tabular}{|c|c|c|c|c|c|c|c|c|c|}
\hline \multirow[b]{3}{*}{ Common name } & \multirow[b]{3}{*}{ Leaf shape ${ }^{\mathrm{z}}$} & \multicolumn{4}{|c|}{$2014-15$} & \multicolumn{4}{|c|}{$2015-16$} \\
\hline & & \multicolumn{4}{|c|}{ Green period $(\mathrm{d})^{\mathrm{y}}$} & \multirow[b]{2}{*}{ Green period $(d)^{y}$} & \multirow[b]{2}{*}{ Slope $\mathrm{e}^{\mathrm{x}}$} & \multirow[b]{2}{*}{$\mathrm{D}_{50}{ }^{\mathrm{w}}$} & \multirow[b]{2}{*}{$R^{2}$} \\
\hline & & Green-down & Slope ${ }^{\mathrm{x}}$ & $\mathrm{D}_{50} \mathrm{w}$ & $R^{2}$ & & & & \\
\hline Blood iris & $\mathrm{B}$ & $60.2 c$ & -0.0339 & 69.9 & 0.9906 & $44.2 \mathrm{~d}$ & -0.0429 & 56.2 & 0.9888 \\
\hline 'Careless Sally' siberian iris & $\mathrm{B}$ & $47.8 \mathrm{~d}$ & -0.0374 & 60.1 & 0.9828 & $44.1 \mathrm{~d}$ & -0.0198 & 57.5 & 0.9909 \\
\hline 'Chinensis' milky iris & B & $50.1 \mathrm{~d}$ & -0.0538 & 56.5 & 0.9952 & $42.5 \mathrm{~d}$ & -0.0319 & 51.7 & 0.9790 \\
\hline 'Loyalty' japanese water iris & $\mathrm{B}$ & $46.0 \mathrm{~d}$ & -0.0361 & 58.7 & 0.9919 & $31.6 \mathrm{e}$ & -0.0317 & 44 & 0.9928 \\
\hline Roof iris & $\mathrm{F}$ & $85.9 \mathrm{~b}$ & -0.0431 & 88.0 & 0.9828 & $77.8 \mathrm{~b}$ & -0.0205 & 78.9 & 0.9905 \\
\hline Yellow flag & $S$ & $65.5 c$ & -0.0732 & 66.8 & 0.9901 & $60.6 c$ & -0.0354 & 63.6 & 0.9863 \\
\hline Mean & & 53.8 & -0.0434 & 62.3 & 0.9888 & 46.7 & -0.0370 & 54.8 & 0.9883 \\
\hline 'Bryce Leigh' louisiana iris & $S$ & $-^{\mathrm{t}}$ & -0.0201 & 77.8 & 0.9022 & - & -0.0646 & 76.2 & 0.9273 \\
\hline Bar-shaped & & $59.0 \mathrm{~B}^{\mathrm{s}}$ & -0.0360 & 62.1 & 0.9608 & $50.7 \mathrm{C}$ & -0.0389 & 54.2 & 0.9786 \\
\hline Fan-shaped & & $101.5 \mathrm{~A}$ & -0.0361 & 93.2 & 0.9577 & $98.4 \mathrm{~A}$ & -0.0269 & 82.9 & 0.9674 \\
\hline \multirow[t]{2}{*}{ Sword-shaped } & & $61.8 \mathrm{~B}$ & -0.0464 & 63.8 & 0.9775 & $60.2 \mathrm{~B}$ & -0.0471 & 56.5 & 0.9721 \\
\hline & & Green-up & & & & & & & \\
\hline 'Black Swan' german iris & $\mathrm{F}$ & $37.5 \mathrm{a}$ & 0.0560 & 40.7 & 0.9921 & $40.4 \mathrm{a}$ & 0.0585 & 35.6 & 0.9875 \\
\hline Blood iris & B & $2.2 \mathrm{c}$ & 0.0267 & 58.6 & 0.9830 & $19.0 \mathrm{~d}$ & 0.0368 & 46.1 & 0.9916 \\
\hline 'Careless Sally' siberian iris & B & - & 0.0298 & 65.6 & 0.9918 & $8.1 \mathrm{e}$ & 0.0355 & 52.6 & 0.9914 \\
\hline 'Chinensis' milky iris & $\mathrm{B}$ & $33.7 \mathrm{a}$ & 0.0923 & 36.3 & 0.9933 & $25.1 \mathrm{c}$ & 0.0969 & 44.9 & 0.9971 \\
\hline Japanese water iris & $\mathrm{B}$ & - & 0.0527 & 59.6 & 0.9916 & - & 0.0370 & 53.0 & 0.9923 \\
\hline Long-leafed flag & $S$ & $12.3 \mathrm{~b}$ & 0.0416 & 56.8 & 0.9970 & $35.8 \mathrm{~b}$ & 0.0480 & 34.2 & 0.9964 \\
\hline 'Loyalty' japanese water iris & B & $12.0 \mathrm{~b}$ & 0.0586 & 52.1 & 0.9971 & $8.5 \mathrm{e}$ & 0.0348 & 46.6 & 0.9906 \\
\hline Bar-shaped & & $19.7 \mathrm{C}$ & 0.0494 & 53.5 & 0.9841 & $21.8 \mathrm{~B}$ & 0.0437 & 46.0 & 0.9846 \\
\hline Fan-shaped & & $47.2 \mathrm{~A}$ & 0.0397 & 40.5 & 0.9824 & $48.8 \mathrm{~A}$ & 2.0000 & 31.8 & 0.9885 \\
\hline Sword-shaped & & $34.3 \mathrm{~B}$ & 0.0484 & 46.8 & 0.9789 & $48.9 \mathrm{~A}$ & 0.0351 & 33.5 & 0.9848 \\
\hline
\end{tabular}

${ }^{\mathrm{z}} \mathrm{B}=$ bar shaped leaf; $\mathrm{F}=$ fan shaped leaf; $\mathrm{S}=$ sword shaped leaf.

${ }^{y}$ Number of days when the percentage of green leaves was more than $50 \%$, as determined according to Eq. [1] during the green-down or green-up period in this study

${ }^{x}$ Slope defines the steepness of the predicted curve calculated by Eq. [1].

${ }^{\mathrm{w}} \mathrm{D}_{50}$ is the number of days when each species/cultivar was determined to be halfway between its maximum and minimum green leaf ratio calculated by Eq. [1].

'Within columns, means green period of species/cultivars followed by a different lowercase letter are significantly different at $P \leq 0.05$ according to Duncan's multiple range test.

"Percentage of green leaves was always below $50 \%$, so green period was $0 \mathrm{~d}$ during the green-down or green-up period in this study.

tPercentage of green leaves was always more than $50 \%$, so green period was the same as days of the green-down (120 d) or green-up ( $70 \mathrm{~d})$ period.

${ }^{s}$ Within columns, means average green period of the same leaf shape followed by a different uppercase letter are significantly different at $P \leq 0.05$ according to Duncan's multiple range test.

cultivars are also available (Streich and Steinegger, 2003). The abundant genetic variation in green period in herbaceous perennials should encourage additional study in this field.

It is important for new iris cultivar breeding to determine whether modifying winter color retention and spring recovery response may be achievable without a simultaneous loss in cold tolerance. The deciduous or evergreen iris phenotypes experienced different cold acclimation time in the field trial which might lead to differences in their cold tolerance (Walworth and Warner, 2009). Thus, we determined leaf $\mathrm{LT}_{50}$ of 12 iris species and cultivars by artificial cold acclimation, similar to the method of Guo et al. (2006) during the vigorous growth period. It turned out that there was no linear regression relationship between green period and leaf $\mathrm{LT}_{50}$ in the different iris species and cultivars. Deciduous iris species, such as yellow flag and blood iris, exhibited significantly lower leaf $\mathrm{LT}_{50}$ s than that of japanese iris. Our results with irises are broadly consistent with the 
Table 3. Average predicted green period during the entire green-up and green-down period and average leaf lethal temperature $\left(\mathrm{LT}_{50}\right)$ of 12 iris species/cultivars by artificial cold acclimation in both years.

\begin{tabular}{|c|c|c|c|c|}
\hline Common name & Leaf shape ${ }^{\mathrm{z}}$ & Green period $(d)^{\mathrm{y}}$ & $\mathrm{LT}_{50}\left({ }^{\circ} \mathrm{C}\right)^{\mathrm{x}}$ & $R^{2 \mathrm{w}}$ \\
\hline 'Black Swan' german iris & $\mathrm{F}$ & $137.0 \mathrm{a}^{\mathrm{v}}$ & $-0.7 \mathrm{~b}$ & 0.9712 ** \\
\hline Blood iris & $\mathrm{B}$ & $25.8 \mathrm{~g}$ & $-1.8 \mathrm{~d}$ & 0.9895 ** \\
\hline 'Careless Sally' siberian iris & $\mathrm{B}$ & $49.1 \mathrm{f}$ & $-2.3 \mathrm{e}$ & 0.9554 ** \\
\hline 'Chinensis' milky iris & $\mathrm{B}$ & $75.7 \mathrm{~d}$ & $-1.4 \mathrm{c}$ & 0.9559 ** \\
\hline Japanese water iris & $\mathrm{B}$ & $64.5 \mathrm{e}$ & $-1.0 \mathrm{~b}$ & 0.9114 ** \\
\hline Long-leafed flag & $S$ & $24.0 \mathrm{~g}$ & $-1.5 \mathrm{~cd}$ & $0.8985^{* *}$ \\
\hline Yellow flag & $S$ & $93.9 c$ & $-2.6 \mathrm{f}$ & $0.9685^{* *}$ \\
\hline Mean & & 70.8 & -1.6 & \\
\hline 'Bryce Leigh' louisiana iris & $S$ & $-^{\mathrm{u}}$ & $-4.3 \mathrm{~h}$ & $0.9384^{*}$ \\
\hline Japanese iris & $\mathrm{F}$ & - & $-1.7 \mathrm{~cd}$ & $0.9775^{* *}$ \\
\hline Small-flower iris & $\mathrm{B}$ & - & $-6.9 \mathrm{i}$ & $0.9376^{*}$ \\
\hline Mean & & - & -4.3 & \\
\hline \multicolumn{5}{|l|}{ Leaf shape } \\
\hline Sword-shaped & & $102.6 \mathrm{~B}$ & $-2.8 \mathrm{~B}$ & \\
\hline
\end{tabular}

* Significant at the $0.05 P$ level.

** Significant at the $0.01 P$ level.

${ }^{\mathrm{z}} \mathrm{B}=$ bar shaped leaf; $\mathrm{F}=$ fan shaped leaf; $\mathrm{S}=$ sword shaped leaf.

${ }^{y}$ Average green period during the entire green-down and green-up in both years.

${ }^{\mathrm{x}}$ Average leaf $\mathrm{LT}_{50}$ with artificial cold acclimation in both years; $\left(1.8 \times{ }^{\circ} \mathrm{C}\right)+32={ }^{\circ} \mathrm{F}$.

${ }^{\mathrm{w}} \mathrm{R}$-squared of leaf $\mathrm{LT}_{50}$.

'Within columns, means green period of species/cultivars followed by a different lowercase letter are significantly different at $P \leq 0.05$ according to Duncan's multiple range test.

uPercentage of green leaves was always over $50 \%$, so green period was the same as days of the entire green-down and green-up (190 d) period in this study.

${ }^{t}$ Within columns, means average green period of the same leaf shape followed by a different uppercase letter are significantly different at $P \leq 0.05$ according to Duncan's multiple range test.

Table 4. Linear regression analysis on average predicted green period during the entire green-up and green-down period and average leaf lethal temperature $\left(\mathrm{LT}_{50}\right)$ for 12 iris species/cultivars in both years.

\begin{tabular}{lrccc}
\hline Source of variation & df & Sum of squares & Mean squares & $\boldsymbol{F}$ statistic \\
\hline Regression & 1 & 6.476 & 6.476 & 1.834 \\
Error & 11 & 35.307 & 3.531 & 0.205 \\
Total & 12 & 41.783 & & \\
\hline
\end{tabular}

observations of Streich and Steinegger (2003) on daylilies, where cold tolerance was not related to the evergreen or deciduous type of daylily. Pompeiano et al. (2014) found that japanese lawn grass (Zoysia japonica) generally exhibited less winter injury and better freeze tolerance but lower color retention in the field. However, no relationship was found between winter injury and autumn growth in either year of the study for zoysiagrass species/cultivars. Brummer et al. (2000) provided genetic evidence for understanding the relationship between fall dormancy and winter survival in alfalfa (Medicago sativa) that may enable us to devise schemes to improve winterhardiness while simultaneously reducing dormancy in iris. Besides, color retention and recovery of plants are not only due to plant cold resistance but also the result of the physiological state of plants, air humidity, soil fertility, and especially, photoperiod and light intensity effects (Guo et al., 2006).

Several works on genes associated with green period cold tolerance should inspire further research in iris. Guo et al. (2012) reported that no significant correlation existed between $\mathrm{LT}_{50}$ and the green period in 96 zoysiagrass accessions $(r=0.198, P=0.054)$ and molecular markers associated with these two traits were completely different. It verified that the evergreen trait was controlled by a single recessive nuclear gene in hazelnut [Corylus avellana (Thompson et al., 1985)] and 'Evergreen' peach [Prunus persica (Rodriguez-A et al., 1994)], whereas inherited in a dominant manner in daylilies (Dow, 2012; Stout, 1940).
Thus, crosses of evergreen iris type with different wild-type deciduous ones are needed to understand how the evergreen trait is inherited.

In our observations, green color enhancement is largely due to new growth during the late fall in iris. Evergreen iris species and cultivars such as japanese iris and louisiana irises grow in the winter during the intermittent periods when temperatures rise above freezing and liquid water is available. Winter dormancy may be the main impediment that limits the garden use of deciduous irises in the Yangtze Delta. The present study confirmed no significant association of green period with foliar cold tolerance, which indicated that concurrent selection for both strong winterhardiness and long green period should be possible in iris. The genetic 
makeup of evergreen iris species, dormancy characteristics, and environmental factors might influence iris winter performance.

\section{Literature cited}

Adams, W.W., III., C.R. Zarter, V. Ebbert, and B. Demmig-Adams. 2004. Photoprotective strategies of overwintering evergreens. Bioscience 54:41-49.

Austin, C. and J.W. Waddick. 2005. Irises: A gardener's encyclopedia. Timber Press, Portland, OR.

Baltensperger, A.A. 1962. Reduce dormancy of bermudagrass by soil heating. Rpt. Turfgrass Resources [Arizona], p. 18-22.

Behrens, T. and W. Diepenbrock. 2006. Using digital image analysis to describe canopies of winter oilseed rape (Brassica napus L.) during vegetative developmental stages. J. Agron. Crop Sci. 192:295-302.

Brummer, E.C., M.M. Shah, and D. Luth. 2000. Reexamining the relationship between fall dormancy and winter hardiness in alfalfa. Crop Sci. 40:971-977.

China Flora. 1985. The flora of China. 16th ed. Science Press, Beijing, China.

Dow, M.A. 2012. Daylily genetics part 5: Foliage, growth, flowering, and rebloom. 18 June 2016. <https://www.academia. edu/29196980/Daylily_Genetics_Part_ 5_Foliage_Growth_Flowering_and_ Rebloom_-_with_references>.

Esmaili, S. and H. Salehi. 2012. Effects of temperature and photoperiod on postponing bermudagrass (Cynodon dactylon [L.] Pers.) turf dormancy. J. Plant Physiol. 169:851-858.

Guo, H.L., J.X. Liu, X.H. Zhu, and A.G. Guo. 2006. Evaluation of cold resistance of zoysia hybrids. Acta Agrestia Sinica 14:24-28.

Guo, H.L., J.P. Xuan, J.X. Liu, Y.M. Zhang, and Y.Q. Zheng. 2012. Association of molecular markers with cold tolerance and green period in zoysiagrass (Zoysia Willd.). Breed. Sci. 62:320-327.

Han, Y.L. 2008. Effects of $\mathrm{Pb}$ on physiological response of Iris halophila. J. Guangxi Agr. Biol. Sci. 27:417-420.

Hu, Y.H. and Y.E. Xiao. 2012. Hygric irises. lst ed. Science Press, Beijing, China.

Kikuzawa, K. and M.J. Lechowicz. 2011. Foliar habit and leaf longevity. 18 June 2016. <http://link.springer.com/ chapter/10.1007/978-4-431-539186_l>.
Li, D.Q., G.Q. Wang, K. Li, J.P. Zhang, and Y.P. Xia. 2016. Effects of chlorocholine chloride and prohexadione-Ca on rhizome growth and lateral bud production in Iris germanica L. J. Hort. Sci. Biotechnol. 91:396-403.

Li, H.S. 2000. Principles and technology of plant physiological and biochemical experiments. 1st ed. Higher Educucation Press, Beijing, China.

Loreau, M. and A. Hector. 2001. Partitioning selection and complementarity in biodiversity experiments. Nature 412:7276.

Luscier, J.D., W.L. Thompson, J.M. Wilson, B.E. Gorham, and L.D. Dragut. 2006. Using digital photographs and object-based image analysis to estimate percent ground cover in vegetation plots. Front. Ecol. Environ 4:408-413.

Motulsky, H. and A. Christopoulos. 2004. Fitting models to biological data using linear and nonlinear regression: A practical guide to curve fitting. Oxford Univ. Press, New York, NY.

Okeyo, D.O., J.D. Fry, D. Bremer, C.B. Rajashekar, M. Kennelly, A. Chandra, D.A. Genovesi, and M.C. Engelke. 2011. Freezing tolerance and seasonal color of experimental zoysiagrasses. Crop Sci. 51:2858-2863.

Patrignani, A. and T.E. Ochsner. 2015. Canopeo: A powerful new tool for measuring fractional green canopy cover. Agron. J. 107:2312-2320.

Patton, A.J., G.A. Hardebeck, D.W. Williams, and Z.J. Reicher. 2004. Establishment of bermudagrass and zoysiagrass by seed. Crop Sci. 44:2160-2167.

Pompeiano, A., N. Grossi, and L. Guglielminetti. 2014. Winter color retention and spring green-up of zoysiagrass genotypes in southern Europe. Eur. J. Hort. Sci. 79:158-166.

Qian, Y., S. Ball, Z. Tan, A. Koshi, and S. Wilhelm. 2001. Freezing tolerance of six cultivars of buffalograss. Crop Sci. 41:11741178.

Richardson, M.D., D.E. Karcher, and L.C. Purcell. 2001. Quantifying turfgrass cover using digital image analysis. Crop Sci. 41:1884-1888.

Richardson, M.D. 2002. Turf quality and freezing tolerance of 'Tifway' bermudagrass as affected by late-season nitrogen and trinexapac-ethyl. Crop Sci. 42:16211626.

Rodriguez-A, J., W.B. Sherman, R. Scorza, M. Wisniewski, and W.R. Okie. 1994. 'Evergreen' peach, its inheritance and dormant behavior. J. Amer. Soc. Hort. Sci. 119:789-792.
Schwab, P.M., D.K. Barnes, and C.C. Sheaffer. 1996. The relationship between field winter injury and fall growth score for 251 alfalfa cultivars. Crop Sci. 36:418426.

Stout, A.B. 1940. Foliage habits of daylilies. Herbertia 7:157-165.

Streich, A. and D. Steinegger. 2003. G001412 daylilies. 3 Nov. 2016. <http:// digitalcommons.unl.edu/cgi/viewcontent. cgi?article $=2718 \&$ context $=$ extensionhist $>$.

Tang, Y.L., L. Wu, Y.J. Lu, S.P. Li, and Z.H. Yang. 2005. Application of iris on subtropical ecological gardens. J. Zhejiang For. Sci. Technol. 25:62-65.

Thompson, M.M., D.C. Smith, and J.E. Burgess. 1985. Nondormant mutants in a temperate tree species, Corylus avellana L. Theor. Appl. Genet. 70:687-692.

Thorp, K.R., B.L. Steward, A.L. Kaleita, and W.D. Batchelor. 2007. Using aerial hyperspectral remote sensing imagery to estimate corn plant stand density. Trans. Amer. Soc. Agr. Biol. Eng. 51: 311-320.

Walworth, A.E. and R.M. Warner. 2009. Differential cold acclimation ability of Petunia spp. HortScience 44:12191222.

Wang, G.Q., D.Q. Li, J.P. Zhang, and Y.P. Xia. 2014. Comparison of cold tolerance within 6 cultivars of Iris germanica. Yuan Yi Xue Bao 41:773-780.

Yin, Q. and H. Cheng. 2010. Landscape use of louisiana iris. China Flowers Hort. 22:29.

Zhang, J. 2012. A study on ecological habits and landscape application of Iris hexagonus. Zhejiang Agr. For. Univ., Lin'an, China, MS Diss.

Zhang, Q., C. Zhu, T. Jiang, and S. Becker. 2005. Mid-Pleistocene environmental reconstruction based on Xiashu loess deposits in the Yangtze Delta, China. Quat. Intl. 135:131-137.

Zhang, J.P., D.F. Wu, and Y.P. Xia. 2013a. Landscape application and wild resource investigation of evergreen perennials in Zhejiang province. Chinese Landscape Architecture 2013:65-71.

Zhang, L., M. Liu, G. Qiao, J. Jiang, Y. Jiang, and R. Zhuo. 2013b. Transgenic poplar "NL895" expressing CPFATB gene shows enhanced tolerance to drought stress. Acta Physiol. Plant. 35: 603-613

Zhou, Y.Z., H.Z. Cheng, W.J. Zhang, and W.T. Lv. 2010. Study on introduction and fruit character of louisiana iris in Suzhou. Northern Hort. 2010:7375 . 